\title{
PENGARUH DOSIS SUBLETAL EKSTRAK SAMBILATA (ANDROGRAPHIS PANICULATA NEES) TERHADAP AKTIVITAS MUSUH ALAMI DAN KEPERIDIAN WERENG HIJAU, NEPHOTETTIX VIRESCENS DISTANT
}

\author{
I Nyoman Widiarta ${ }^{1}$, dan Dede Kusdiaman ${ }^{1}$
}

\begin{abstract}
Effect of sublethal doses of sambilata extract to the fecundity and natural enemies activity of the green leafhopper, Nepothettix virescens Distant. Sambilata (Andrographis paniculata) is a tropical herb which has antifeeding property and could reduce rice tungro virus transmission by the rice green leafhopper (GLH), Nephotettix virescens. Series of test were conducted to clarify the effect of sublethal doses of sambilata to the fecundity and natural enemies activity of the GLH. The objective of the test was to know wether sublethal dose of sambilata could cause physiological or ecological resurgence. The results of test showed that foliar spraying of sambilata extract at concentration of 100 and 1000 ppm to rice seedlings reduced the GLH females's fecundity. Spraying sambilata extract up to dose of $100 \mathrm{ppm}$ on rice seedlings and GLH did not reduce Lycosa preying activity. Egg parasitoid activity was not affected by sambilata application on rice seedlings bore GLH eggs. Thus the probability of sublethal dose of sambilata to cause physiological or ecological resurgence was low.
\end{abstract}

Key words : green leafhopper, sambilata, sublethal effect, resurgence

\section{PENDAHULUAN}

Wereng hijau Nephotettix virescens dan wereng loreng Recilia dorsalis merupakan vektor utama virus penyebab penyakit tungro. Di antara spesies wereng hijau dan wereng loreng terdapat perbedaan efisiensi menularkan virus. Rentang efisiensi penularan virus oleh populasi $N$. virescens berkisar 35-83\% (Rivera \& Ou, 1965), dibandingkan dengan $N$. nigropictus yang rentang efisiensinya $0-27 \%$ (Ling, 1979). Spesies wereng hijau lainnya seperti $N$. malayanus dan $N$. parvus memiliki kemampuan menularkan virus berturut-turut 40\% (IRRI, 1973) dan 7\% (Rivera et al., 1968), lebih rendah daripada $N$. virescens. Dengan demikian $N$. virescens merupakan vektor yang paling efisien menularkan virus tungro dibandingkan dengan jenis vektor lainnya.

Kepadatan populasi wereng hijau berfluktuasi, kebanyakan hanya meningkat pada saat tanaman padi muda sampai pertengahan pertumbuhan tanaman pada pola tanam padi-padi-padi, tetapi pada pola tanam padi-padi-bera/palawija kepadatan populasi kebanyakan tidak meningkat sama sekali (Widiarta et al., 1999). Hasil analisis Widiarta et al. (1999) dengan menggunakan analisis faktor kunci (keyfactor) menunjukkan bahwa kematian pada periode nimfa, termasuk pemencaran imago, menjadi faktor kematian kunci untuk populasi wereng hijau pada pola padi-padi-padi maupun padi-padi-bera/palawija. Analisis lebih lanjut dengan analisis tanggap bilangan (numerical analysis) diketahui bahwa pada pola tanam padi-padi-padi tidak ditemukan adanya tanggap bilangan antara kematian nimfa dengan kepadatan populasi pemangsa, tetapi tanggap bilangan ditemukan pada pola tanam padi-padi-bera/palawija. Hal tersebut menunjukkan adanya perbedaan faktor yang mempengaruhi pertumbuhan populasi. Peranan pemencaran imago cukup besar pada pola padi-padipadi, sedangkan pada pola padi-padi-bera/palawija, meningkatnya kepadatan populasi pemangsa erat terkait dengan peningkatan kematian pada periode nimfa. Implikasi dari temuan ini untuk pengendalian tungro adalah pada pola tanam padi-padipalawija/bera konservasi pemangsa sangat penting untuk menekan populasi wereng hijau yang menjadi vektor penyakit tungro, sedangkan pada daerah pola tanam padi-padi-padi, upaya yang dapat dilakukan ialah mengurangi kemampuan pemerolehan dan penularan virus oleh wereng hijau sebagai komponen utama pengendalian.

Penekanan aktivitas mengisap wereng hijau sebagai vektor penyakit virus dilaporkan efektif membatasi penularan virus. Beberapa bahan kimia sintetik seperti imidakloprid diketahui dapat menekan

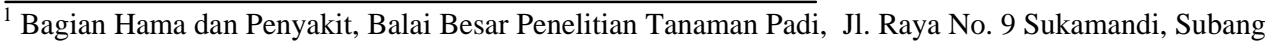


aktifvitas mengisap beberapa spesies kutu daun seperti Myzus persicae dan Myzus nicotiana (Nauen et al., 1998). Kartap, bensultap dan nitempiram pada dosis subletal juga mengurangi kemampuan mengisap wereng hijau $N$. cincticeps maupun $N$. virescens (Widiarta et al., 1997 b). Ekstrak sambilata Andrographis paniculata juga memiliki kemampuan mengurangi aktivitas mengisap kedua spesies wereng hijau tersebut (Widiarta et al., 1997 a, b).

Hasil pengujian di rumah kaca menunjukkan bahwa aplikasi dosis subletal ekstrak sambilata dapat menekan pemerolehan maupun penularan virus tungro oleh wereng hijau (Widiarta et al., 1998). Dengan demikian sambilata memiliki prospek sebagai salah satu komponen teknologi untuk dirakit dalam pendekatan pengendalian terpadu penyakit tungro. Namun, aplikasi insektisida pada dosis subletal pada wereng hijau kemungkinan dapat menyebabkan peningkatan populasi setelah aplikasi (resurjensi) karena proses perubahan pada fisiologi serangga seperti keperidian menjadi meningkat (Chelliah et al., 1980) atau karena proses ekologi melalui gangguan terhadap aktivitas musuh alami (Luckey, 1968). Agar tidak menimbulkan masalah pada masa yang akan datang, perlu diuji pengaruh dosis subletal ekstrak sambilata terhadap keperidian wereng hijau, aktivitas memangsa predator dan kemampuan memarasit musuh alami wereng hijau. Dari percobaan ini diharapkan dapat diketahui kemungkinan dosis subletal ekstrak sambilata dalam menyebabkan peningkatan populasi secara mendadak setelah aplikasi (resurjen).

\section{METODE PENELITIAN}

\section{Penyiapan ekstrak sambilata}

Ekstrak kasar sambilata yang digunakan dalam penelitian ini diperoleh dari hasil ekstraksi tanaman sambilata yang tumbuh secara alami dari Jatinangor, Sumedang. Secara garis besar, proses pembuatan ekstrak kasar sambilata adalah sebagai berikut: Bagian daun dan batang tanaman sambilata dipotong-potong sepanjang $3 \mathrm{~cm}$, dipisahkan bagian daun dari batang, kemudian dikeringkan. Batang dan daun tanaman yang telah kering sebanyak 0,8 kg direndam dalam $4 \mathrm{l}$ metanol teknis dalam tabung, selanjutnya dilakukan maserasi selama 7 hari. Hasil maserasi disaring (filtrasi), kemudian filtrat tersebut dievaporasi dengan menggunakan evaporator vakum sampai berbentuk pasta.

\section{Perbanyakan wereng hijau}

Pembiakan $N$. virescens dilakukan di rumah kaca. Dua puluh pasang imago setelah periode praoviposisi dimasukkan kedalam kotak plastik mika dengan ukuran $30 \mathrm{~cm}$ x $28 \mathrm{~cm}$ x $25 \mathrm{~cm}$ yang berisi bibit tanaman padi varietas IR 64 umur 15 hari setelah sebar (HSS) sebagai sumber makanan. Pasangan serangga dibiarkan meletakkan telur selama seminggu, kemudian dipindahkan pada kotak yang lain untuk peneluran berikutnya. Dengan cara demikian didapat serangga dengan umur yang seragam dalam satu kurungan pemeliharaan. Untuk pengujian digunakan serangga nimfa besar (nimfa instar 4 dan 5) atau imago jantan dan betina 3 hari setelah ganti kulit.

\section{Uji kemungkinan sebagai penyebab resurjensi}

Parasitasi telur. Benih padi varietas TN1 sebanyak 10 butir disebar dalam gelas plastik $240 \mathrm{ml}$ yang diisi dengan tanah sebagai media tumbuh dan dimasukan ke dalam kotak kurungan dengan ukuran $30 \mathrm{~cm}$ x 28 $\mathrm{cm} \times 25 \mathrm{~cm}$. Setelah bibit tanaman padi berumur 15 hari, ke dalam kotak kurungan dimasukkan pasangan imago wereng hijau 3 hari setelah ganti kulit (2 pasang per tanaman/20 pasang per gelas plastik) dan dibiarkan selama 7 hari untuk memberi kesempatan pada imago betina wereng hijau meletakkan telurnya. Tujuh hari kemudian tanaman padi yang berisi telur wereng hijau disemprot dengan ekstrak daun sambilata sesuai dengan konsentrasi yang diujikan mengacu pada laporan Widiarta et al. (1997b) dan Widiarta et al. (1998). Setelah kering bibit tanaman padi diletakkan di areal pertanaman padi selama 7 hari untuk memberi kesempatan pada parasitoid untuk memarasit telur wereng hijau mengikuti metode Otake (1970). Setelah itu dihitung jumlah telur yang terparasit dan yang tidak di bawah mikroskop binokuler.

Kemampuan memangsa laba-laba. Laba-laba dewasa Lycosa pseudoannulata diperoleh dari lahan percobaan pertanaman padi Balai Besar Penelitian Tanaman Padi di Sukamandi. Laba-laba yang digunakan memiliki bobot tubuh yang hampir sama, yaitu sekitar $6 \mathrm{mg}$. Pada perlakuan pertama, dua bibit padi varietas TN1 yang berumur 10 hari disemprot 
dengan ekstrak daun sambilata sesuai dengan konsentrasi perlakuan mengacu pada laporan Widiarta et al. (1997b) dan Widiarta et al. (1998). Setelah itu dimasukkan ke dalam tabung kaca (diameter $2 \mathrm{~cm}$, tinggi $17 \mathrm{~cm}$ ) dan dibiarkan sampai kering 24 jam. Seekor laba-laba yang telah mengalami pelaparan 24 jam dan 10 ekor wereng hijau dewasa dimasukkan ke dalam tabung kaca yang di dalamnya terdapat bibit tanaman padi yang telah diberi perlakuan. Setelah 24 jam dihitung jumlah wereng hijau yang dimakan. Pada perlakuan kedua tanaman padi tidak disemprot dengan ekstrak daun sambilata, tetapi wereng hijaunya yang disemprot. Setelah 24 jam dihitung jumlah wereng hijau yang dimakan.

Rancangan yang digunakan adalah rancangan acak lengkap yang terdiri dari 6 perlakuan dengan 6 kali ulangan. Perlakuan lengkapnya adalah sebagai berikut: 1) bibit tanaman padi disemprot dengan aquades (BS0), 2) bibit tanaman padi disemprot ekstrak sambilata 100 ppm (BS100), 3) bibit tanaman padi disemprot ekstrak sambilata 1000 ppm (BS1000), 4) wereng hijau disemprot dengan aquades (WS0), 5) wereng hijau disemprot dengan ekstrak sambilata 100 ppm (WS100), 6) wereng hijau disemprot ekstrak sambilata 1000 ppm (WS1000).

Keperidian wereng hijau. Benih padi varietas TN1 sebanyak 10 butir disebar dalam gelas plastik $240 \mathrm{ml}$ yang diisi dengan tanah sebagai media tumbuh. Setelah berumur 15 hari, bibit disemprot dengan ekstrak daun sambilata sesuai dengan konsentrasi yang diujikan mengacu pada laporan Widiarta et al. (1997b) dan Widiarta et al. (1998). Setelah kering bibit tanaman padi dimasukkan ke dalam kotak kurungan dengan ukuran $30 \mathrm{~cm}$ x $28 \mathrm{~cm}$ x $25 \mathrm{~cm}$. Pasangan imago wereng hijau 3 hari setelah ganti kulit (2 pasang per tanaman atau 20 pasang per gelas plastik) dimasukkan ke dalam kurungan kasa yang berisi bibit tanaman padi yang telah diberi perlakuan. Serangga dibiarkan selama 7 hari untuk memberi kesempatan pada imago betina wereng hijau meletakkan telurnya. Setelah 7 hari bibit tanaman padi diambil dan dilakukan pengamatan jumlah telur yang diletakkan.

Pengamatan dilakukan di bawah mikroskop binokuler dengan cara membelah batang tanaman padi, karena telur telur wereng hijau terletak di antara jaringan parenkima. Telur yang telah dihitung kemudian diletakkan dalam cawan petri yang dialasi dengan kertas merang yang dijaga kelembabannya. Jumlah telur yang menetas diamati untuk mengetahui persentase telur yang menetas.

\section{HASIL DAN PEMBAHASAN}

Efek ekstrak sambilata terhadap keperidian wereng hijau. Apllikasi ekstrak sambilata dengan konsentrasi 100 ppm dan 1000 ppm menurunkan jumlah telur yang diletakan oleh wereng hijau masingmasing sebesar $45 \%$ dan $43 \%$ jika dibandingkan dengan kontrol (Tabel 1).

Proporsi telur yang menetas lebih rendah pada telur-telur yang diberikan perlakuan sambilata, meskipun secara statistik tidak berbeda nyata antara

Tabel 1. Dampak aplikasi ekstrak sambilata terhadap keperidian wereng hijau N. virescens

\begin{tabular}{ccc}
\hline Perlakuan $(\mathrm{ppm})$ & $\begin{array}{c}\text { Rata-rata jumlah telur yang } \\
\text { diletakkan }\end{array}$ & S.E. (standard error) \\
\hline 0 & 417,2 & 32,1 \\
100 & $229,8 * *$ & 17,3 \\
1000 & $236,7 * *$ & 14,0 \\
\hline
\end{tabular}

** Berbeda nyata antara perlakuan dengan kontrol (0 ppm )

Tabel 2. Dampak aplikasi sambilata terhadap penetasan telur wereng hijau $N$. virescens

\begin{tabular}{cc}
\hline Perlakuan $(\mathrm{ppm})$ & Proporsi telur yang menetas (\%) \\
\hline 0 & 63,3 \\
100 & 56,7 \\
1000 & 58,4 \\
\hline
\end{tabular}

\footnotetext{
** berbeda nyata antara perlakuan dengan kontrol (0 ppm)
} 
perlakuan dengan kontrol (Tabel 2).

Efek ekstrak sambilata terhadap aktifvitas memangsa L. pseudoannulata. Aplikasi ekstrak sambilata sampai dengan konsentrasi 100 ppm tidak mempengaruhi aktivitas memangsa laba-laba pada hari pertama (Tabel 3) maupun pada hari kedua (Tabel 4) untuk perlakuan penyemprotan ekstrak sambilata pada bibit tanaman padi maupun pada wereng hijau. Aplikasi ekstrak sambilata dengan konsentrasi 1000 ppm nyata mengurangi aktivitas memangsa laba-laba pada hari pertama (Tabel 3) maupun hari kedua (Tabel 4) untuk perlakuan penyemprotan ekstrak sambilata pada bibit tanaman padi maupun pada wereng hijau.

Efek ekstrak daun sambilata terhadap tingkat parasitasi telur wereng hijau. Berdasarkan hasil analisis diketahui bahwa perlakukan ekstrak sambilata tidak berpengaruh terhadap tingkat parasititasi telur

Tabel 3. Pengaruh aplikasi sambilata pada aktivitas memangsa laba-laba terhadap wereng hijau $N$. virescens pada hari pertama

\begin{tabular}{|c|c|c|c|}
\hline Perlakuan & $\begin{array}{c}\text { Rata-rata jumlah wereng } \\
\text { hijau dimakan }\end{array}$ & $\begin{array}{c}\text { S.E. } \\
\text { (standard error) }\end{array}$ & $\begin{array}{c}\text { Sintasan laba-laba } \\
(\%)\end{array}$ \\
\hline Bibit diaplikasi air (S0) & 9,14 & 0,46 & 100 \\
\hline $\begin{array}{l}\text { Bibit diaplikasi ekstrak } \\
\text { sambilata } 100 \text { ppm (BS100) }\end{array}$ & 9,00 & 0,58 & 100 \\
\hline $\begin{array}{l}\text { Bibit diaplikasi ekstrak } \\
\text { sambilata } 1000 \text { ppm (BS1000) }\end{array}$ & $7,14 * *$ & 0,51 & 100 \\
\hline $\begin{array}{l}\text { Wereng hijau diaplikasi air } \\
\text { (WS0) }\end{array}$ & 8,71 & 0,52 & 100 \\
\hline $\begin{array}{l}\text { Wereng hijau diaplikasi } \\
\text { ekstrak sambilata } 100 \text { ppm } \\
\text { (WS100) }\end{array}$ & 8,14 & 0,74 & 100 \\
\hline $\begin{array}{l}\text { Wereng hijau diaplikasi } \\
\text { ekstrak sambilata } 1000 \text { ppm } \\
\text { (WS1000) }\end{array}$ & $6,57 * *$ & 0,64 & 100 \\
\hline
\end{tabular}

** berbeda nyata antara perlakuan dengan kontrol (0 ppm)

Tabel 4. Pengaruh aplikasi sambilata pada aktivitas laba-laba terhadap wereng hijau $N$. virescens pada hari kedua

\begin{tabular}{|c|c|c|c|}
\hline Perlakuan & $\begin{array}{c}\text { Rata-rata jumlah wereng } \\
\text { hijau dimakan }\end{array}$ & S.E. (standard error) & $\begin{array}{c}\text { Sintasan laba-laba } \\
(\%)\end{array}$ \\
\hline Bibit diaplikasi air (S0) & 0,86 & 0,46 & 100 \\
\hline $\begin{array}{l}\text { Bibit diaplikasi ekstrak } \\
\text { sambilata } 100 \text { ppm (BS100) }\end{array}$ & 1,00 & 0,58 & 100 \\
\hline $\begin{array}{l}\text { Bibit diaplikasi ekstrak } \\
\text { sambilata } 1000 \text { ppm (BS1000) }\end{array}$ & $2,86^{* *}$ & 0,51 & 100 \\
\hline $\begin{array}{l}\text { Wereng hijau diaplikasi air } \\
\text { (WS0) }\end{array}$ & 1,29 & 0,52 & 100 \\
\hline $\begin{array}{l}\text { Wereng hijau diaplikasi ekstrak } \\
\text { sambilata } 100 \text { ppm (WS100) }\end{array}$ & 1,86 & 0,74 & 100 \\
\hline $\begin{array}{l}\text { Wereng hijau diaplikasi ekstrak } \\
\text { sambilata } 1000 \text { ppm (WS1000) }\end{array}$ & $3,43 * *$ & 0,65 & 100 \\
\hline
\end{tabular}

** berbeda nyata antara perlakuan dengan kontrol (0 ppm) 
Tabel 5. Dampak aplikasi sambilata terhadap parasitasi telur wereng hijau

\begin{tabular}{ccc}
\hline Perlakuan $(\mathrm{ppm})$ & Jumlah telur sebagai perangkap & Parasitasi (\%) \\
\hline 0 & 4,323 & 7,84 \\
100 & 2,694 & 6,83 \\
1000 & 4,076 & 7,12 \\
\hline
\end{tabular}

** berbeda nyata antara perlakuan dengan kontrol (0 ppm)

yang diletakan oleh wereng hijau (Tabel 5).

Pengaruh aplikasi ekstrak sambilata sampai dengan konsentrasi 100 ppm terhadap kemungkinan terjadinya resurjensi baik resurjensi secara fisiologi maupun ekologis kemungkinannya rendah, dilihat dari keperidian wereng hijau, daya predasi musuh alami (L. pseudoannulata) dan tingkat parasitasi telur wereng hijau oleh parasitoid.

Dari hasil pengujian terhadap keperidian wereng hijau diketahui bahwa aplikasi ekstrak daun sambilata pada konsentrasi 100 dan 1000 ppm tidak meningkatkan jumlah telur yang diletakkan wereng hijau bahkan menurunkan sampai setengahnya. Hal ini sesuai dengan hasil penelitian dampak sambilata yang dilakukan sebelumnya pada serangga lain. Hermawan et al (1993 dan 1998) melaporkan bahwa ekstrak daun sambilata yang disemprotkan pada tanaman kubis dengan konsentrasi 250, 500, dan 1000 ppm dapat mengurangi oviposisi Plutella xylostella, begitu juga terhadap hama gudang Callosobruchus chinensis. Pada penelitian lain Widiarta et al. (2001) melaporkan bahwa aplikasi subletal imidakloprid $(0,01 \mathrm{ppm})$ sebagai antifidan juga tidak meningkatkan jumlah telur yang diletakkan oleh wereng hijau baik $N$. virescens maupun $N$. cincticeps. Dengan demikian pada dosis subletal ekstrak sambilata seperti halnya imidakloprid tidak menjadi perangsang peningkatan keperidian wereng hijau.

Aplikasi ekstrak daun sambilata pada tanaman padi maupun pada wereng hijau sampai konsentrasi 100 ppm tidak mengganggu aktivitas memangsa labalaba. Aplikasi ekstrak daun sambilata 1000 ppm berpengaruh terhadap daya predasi. L. pseudoannulata. Perlakuan ekstrak sambilata tidak berpengaruh terhadap tingkat parasititasi telur wereng hijau oleh parasitoid, pada konsentrasi 100 ppm maupun 1000 ppm. Dengan demikian diketahui bahwa meskipun bahan yang diaplikasikan adalah bahan nabati bukan berarti mutlak aman, harus tepat konsentrasi agar dampaknya terhadap lingkungan minimal.
Penyemprotan ekstrak sambilata dengan konsentrasi 40 - 100 ppm dilaporkan menekan penularan tungro, disebabkan karena berkurangnya kemampuan wereng hijau mengisap dilihat dari jumlah cairan tanaman yang dihisap dan jumlah tusukan stilet pada tanaman padi (Widiarta et al., 1997b; 1998). Dari pengujian ini diketahui ekstrak sambilata juga mengurangi kemampuan memangsa predator (antifidan) meskipun pada konsentrasi yang lebih tinggi 10 kali lipat dibandingkan konsentrasi efektifnya untuk $N$. virescens.

Hal di atas menunjukan bahwa ekstrak sambilata tidak berpengaruh terhadap terjadinya resurjen baik secara fisiologi maupun ekologis bila diaplikasikan dengan konsentrasi dibawah 100 ppm. Resurgensi fisiologi disebabkan oleh meningkatnya jumlah telur yang diletakan oleh serangga betina setelah aplikasi pestisida tertentu (Luckey, 1968). Sebagai contoh ledakan (outbreak) $N$. lugens terjadi setelah penggunaan insektisida deltametrin dan metil paration pada dosis subletal (Chelliah et al., 1980). Sedangkan resurgensi ekologi disebabkan oleh matinya musuh alami (DeBack et al., 1971) atau menurunnya daya parasititasi suatu parasitoid.

\section{SIMPULAN DAN SARAN}

\section{Simpulan}

1. Aplikasi dosis subletal sambilata tidak meningkatkan keperidian wereng hijau

2. Aplikasi dosis subletal sambilata tidak mempengauhi aktivitas memangsa laba-laba sampai konsentrasi 100 ppm, dan parasitasi parasitoid telur

3. Peluang sambilata menyebabkan resurjensi fisiologi maupun ekologi pada wereng hijau rendah

\section{Saran}

Tidak menggunakan ekstrak sambilata dosis subletal pada konsentrasi 1000 ppm atau lebih, karena 
dapat menekan kemampuan laba-laba memangsa wereng hijau, sehingga berpotensi menyebabkan resurjensi secara ekologis.

\section{SANWACANA}

Terimakasih disampaikan kepada Sdr. Oco Rumasa dan Anton Yustiano yang telah membantu dalam pelaksanaan pengujian ini.

\section{DAFTAR PUSTAKA}

Chelliah, S., L.T. Fabellar \& E. Heinrichs. 1980. Effect of sub-lethal doses of three insecticide on the reproductive rate of brown planthopper, Nilaparvata lugens, on rice. Environ. Entomol. 9: 778-780

DeBack, P., D. Rosen \& C. E. Kennett. 1971. Biological control of coccids by introduced natural enemies. In C. B. Huffaker. Biological Control ed. Plenum Press, New York.

Hermawan, W., R. Tsukuda, K. Fujisaki, A. Kobayashi \& F. Nakasuji. 1993. Influence of crude extract from a tropical plant, Andrographis paniculata (Acanthaceae) on suppression of feeding by diamond back moth, Plutella xylostella (Lepidoptera: Yponomeutidae) and the oviposition by the azuki weevil, Callosobruchus chinensis (Coleoptera: Bruchidae). Appl. Entomol. Zool. $28: 251-254$

Hermawan, W., R. Tsukuda, S. Nakajima, K. Fujisaki, dan F. Nakasuji. 1998. Oviposition deterrent activity of andrographolide against the diamond back moth (DMB), Plutella xylostella (Lepidoptera: Yponomeutidae). Appl. Entomol. Zool. 33 (2) : 239- 241.

IRRI. 1973. Annual Report. IRRI Los Banos, Philippines.

Ling, K. C. 1979. Rice Virus Disease. IRRI, Los Banos, Philippines.
Luckey, T. D. 1968. Insecticide hormoligosis. J. Econ. Entomol. 61: 7-12.

Nauen, R., H. Hungenberg, B. Tollo, K. Tietjen \& A. Elbert. 1998. Antifeedant effect, biological efficacy and high affinity binding of imidacloprid to acetylcholine receptors in Myzus persicae and Myzus nicotinae. Pestic. Sci. 53: 133-140.

Otake, A. 1970. Studies on the egg parasites of the smaller brown planthopper, Laodelphax striatellus (Fallen) (Hemiptera: Delphacidae) IV. Seasonal trends in parasitic and dispersal activities, with special reference to Anagrus Flaveolus Waterhouse (Hymenoptera: Myrmaridae). Appl. Entomol. Zool. 5: 95-104.

Rivera, C. T. \& S.H. Ou. 1965. Leafhopper transmission of "tungro" disease of rice. Plant. Dis. Rep. 49: 127-131.

Rivera, C. T. , S.H. Ou \& D.M. Tantera. 1968. Tungro disease of rice in Indonesia. Plant. Dis. Rep. 52: 122-124.

Widiarta, I N., W. Hermawan, S. Oya, S. Nakajima \& F. Nakasuji. 1997a. Antifeedant activity of constitutent of Andrographis paniculata (Acanthaceae) against the green rice leafhopper, Nephotettix cincticeps (Hemiptera: Cicadellidae). Appl. Entomol. Zool. 32: 561566.

Widiarta, I. N., N. Usyati \& D. Kusdiaman. 1997b. Aktivitas antifidan andrografolid dan tiga insektisida sintetis terhadap, Nephotettix virescens (Distant) (Hemiptera: Cicadellidae). Buletin Hama dan Penyakit Tanaman 9: 14-19.

Widiarta, I. N., M. Muhsin \& D. Kusdiaman. 1998. Pengaruh andrografolid dan dua insektisida sintetis, antifidan Nephotettix virescens, terhadap penularan penyakit tungro. Jurnal Perlindungan Tanaman Indonesia 4 : 1 - 8 . 
Widiarta, I. N., D. Kusdiaman \& A. Hasanuddin. 1999. Dinamika populasi Nephotettix virescens pada dua pola tanam padi sawah. Jurnal Perlindungan Tanaman Indonesia 5: 42-49.
Widiarta, I. N., M. Matsumura, Y. Suzuki \& F. Nakasuji. 2001. Effects of sublethal doses of imidaclprid on the fecundity of green leafhoppers, Nephotettix spp. (Hemiptera: Cicadellidae) and their natural enemies. Appl. Entomol. Zool. 36(4) : 501-507. 